\title{
THE USE OF INFRARED THERMOGRAPHY AND GROWTH RATES FOR NONDESTRUCTIVE ANALYSIS ON GREENROOF PLANTS
}

\author{
S. W. Han ${ }^{1}$, J. S. Park ${ }^{2}$, J. S. Kim ${ }^{1}$ \\ ${ }^{1}$ Urban Agriculture Research Division NIHHS, RDA Wanju, Korea \\ ${ }^{2}$ Department of Architectural Engineering Hanyang University Seoul, Korea \\ †Presenting Author: hansgarden@korea.kr \\ *Corresponding Author: achitec@hanyang.ac.kr
}

\begin{abstract}
The increase in impervious area caused by development project has resulted in prone to water management with climate change, which can affect the water cycle, including the ecosystem. LID(low impact development) techniques have been widely applied in order to recover water environment conditions prior to the development reducing the impervious area. Studies have been conducted on optimal types, species, and combinations of rain garden facilities suitable for regional characteristics. We assessed the wet and drought sensitivity of the water relations of six deciduous garden plants at three sites with contrasting water availability of by thermal imagery of foliage temperature and soil water potential. The immersion treatment compared the differences in plant growth between permanent immersion and intermittent immersion conditions. Immersion duration had a consistent influence on vegetation temperature with water stress tolerance species(Liatris spicata, Prunella asiatica Nakai, Mentha arvensis var. piperascens) being warmer(0.5-1.5K) than water stress sensitive species(Hosta longipes, Astilbe rubra Hook. F. \& Thomson ex Hook. f., Chrysanthemum zawadskii var. latilobum). Significantly, mostly foliage plants were well growth on intermittent immersion conditions compared with permanent one. A close correlation $(p<0.001)$ between leaf temperature or modified crops water stress index with NDVI and photosynthetic rate value was obtained.

Thermography is a potentially promising method to accelerate the screening process and thereby enhance species for water stress or drought stress in rain garden.
\end{abstract}

KEYWORDS: Rain Garden, Low Impact Development, Korean Native Plants, Thermal Image Analysis,

\section{INTRODUCTION}

An increase of impermeable environment influenced the circulation of water, including the water ecosystem. Demanding possible ways to perform a distributed water management, the low-impact development(LID) is required, prior to development by normalizing the water circulation through such as transformation from impermeable surface to permeable surface or disconnection with impermeable surface, furthermore it can support the transition to the state of the ecosystem. In particular, by the lack of studies of the thermal imagery analysis of ecosystem vegetative conditions.

\section{EFFECTS OF WATER USE EFFICIENCY}

Index for vegetation growth analysis is crop growth rate, relative growth rate and net assimilation rate. Basic elements for plants growth model are shown below.

$$
\begin{gathered}
C G R=\frac{W_{\text {after }}-W_{\text {before }}}{\mathrm{A}_{\text {ground }}\left(t_{\text {after }}-t_{\text {before }}\right)} \\
R G R=\frac{\ln W_{\text {affer }}-\ln W_{\text {before }}}{t_{\text {after }}-t_{\text {before }}}
\end{gathered}
$$




$$
N A R=\frac{1}{\mathrm{~A}_{\text {ground }}} \bullet \frac{d W}{d t}
$$

Where,

$\mathrm{t}$ : time [day]

A : area $\left[\mathrm{m}^{2}\right]$

$\mathrm{W}$ : weight $\left[\mathrm{g} / \mathrm{m}^{2}\right]$

$\mathrm{dW} / \mathrm{dt}$ : growth rate $\left[\mathrm{g} / \mathrm{m}^{2} \mathrm{~d}\right]$
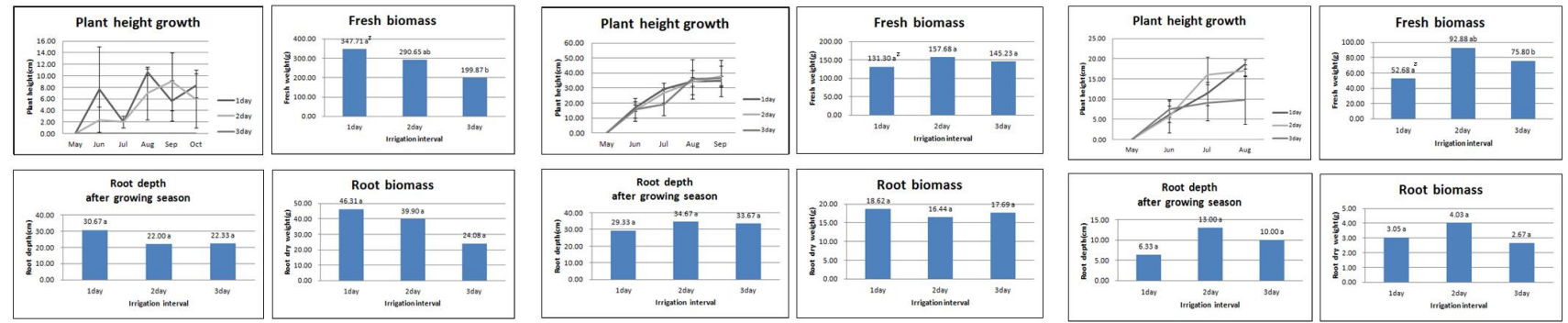

a. Dendranthema zawadskii
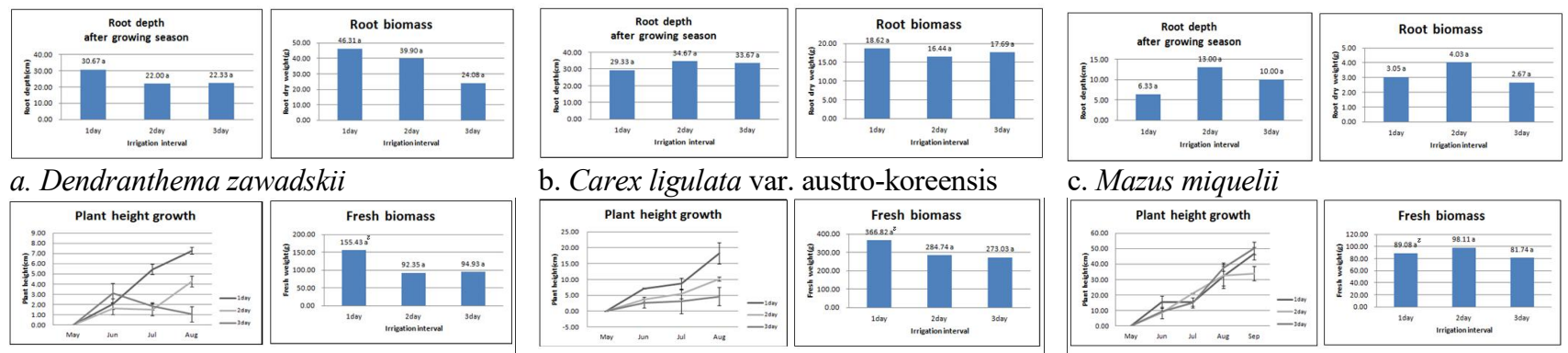

b. Carex ligulata var. austro-koreensis

\section{c. Mazus miquelii}

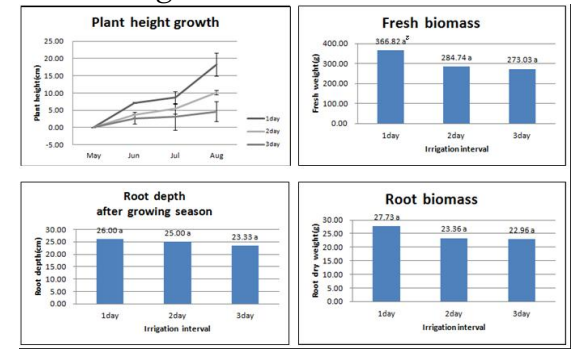

e. Arrhenatherum elatius

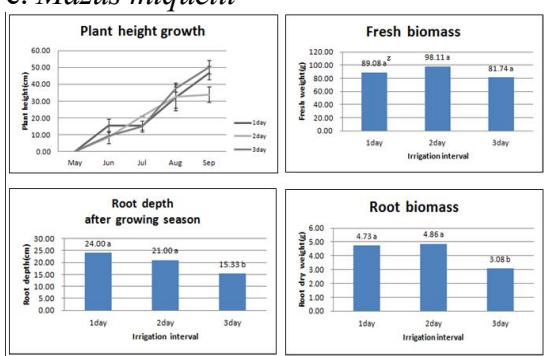

f. Lysimachia nummularia

d. Potentilla dickinsii

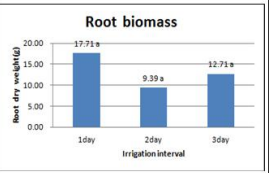

Fig. 1 Growth changes of greenroof plants for LID

\section{CONCLUSIONS}

This work was carried out with the support of "Cooperative Research Program for Agriculture Science \& Technology Development (Project No. PJ010915012017)" Rural Development Administration, Republic of Korea.

\section{REFERENCES}

[1] C. Xu, J. Hong, H. Jia, S. Liang, T. Xu, Life cycle environmental and economic assessment of a LID-BMP treatment train system: A case study in China., J. of Cleaner Production 149(2017)227-237.

[2] D. Scherrer, M.K.F. Bader, C. Korner, Drought-sensitivity ranking of deciduous tree species based on thermal imaging of forest canopoes., Agricultural and Forest Meteorology 151(2011) 1632-1640.

[3] G. Romano, S. Zia, W. Spreer, C. Sanchez, J. Cairns, J.L. Araus., Use of thermography for high throughput phenotyping of tropical maize adaptation in water stress., Compiters and Electronics in Agriculture. 79(2011)67-74

[4] J. Lamba, A.M. Thomson, K.G. Karthikeyan, J.C. Panuska, Effect od best management practice implementation on sediment and phosphorus load reduction at subwatershed and watershed scale using SWAT model., International J. of Sediment Research 31(2016) 386394. 